\title{
PENINGKATAN KUALITAS KESEHATAN IBU DAN ANAK MELALUI PEMANFAATAN BUKU KIA (KESEHATAN IBU DAN ANAK) UNTUK PENCEGAHAN STUNTING
}

\author{
Nur Azizah ${ }^{1}$, Mediyana Sembiring ${ }^{2}$, Isyos Sari Sembiring ${ }^{3}$, Asnika $^{4,}$ Rosmani Sinaga $^{5}$, \\ Devita Purnamasari6 \\ 1,3,5,6 Prodi Kebidanan Program Diploma Tiga Kebidanan STIKes Mitra Husada Medan \\ ${ }^{2,4}$ Prodi Kebidanan Program Sarjana STIKes Mitra Husada Medan

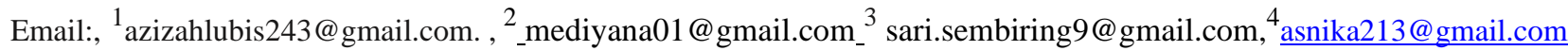 \\ ${ }^{5}$ rosmanisinaga11@gmail.com, ${ }^{6}$ devitapurnamasari129@gmail.com.
}

\begin{abstract}
Abstrak
Stunting merupakan sebuah masalah kurang gizi kronis yang disebabkan oleh kurangnya asupan gizi dalam waktu yang cukup lama, hal ini menyebabkan adanya gangguan di masa yang akan datang yakni mengalami kesulitan dalam mencapai perkembangan fisik dan kognitif yang optimal. Ketidakpahaman ibu yang memiliki balita terhadap informasi yang didapatkan tentang pertumbuhan dan perkembangan balita sehingga menyebabkan balita mengalami stunting. Upaya meningkatkan kelangsungan dan kualitas hidup ibu dan anak dengan pendekatan promotif dan preventif dengan memanfaatkan buku KIA sebagai informasi tentang ibu dan anak sehingga memudahkan ibu untuk dapat memahami kondisi kesehatan bayinya secara mandiri dan meningkatkan praktik keluarga dan masyarakat dalam mememilihara/ merawat kesehatan. Tujuan Pengabdian masyarakat ini dilakukan kepada masyarakat untuk meningkatkan kualitas kemampuan ibu balita dalam memanfaatkan buku KIA . Hasil kegiatan program pengabdian masyarakat yang telah dilakukan menunjukkan dengan Metode Penyuluhan dan membagikan kuesioner untuk menilai pengetahuan sebelum (pre-test) dan sesudah (post-test) diberikan penyuluhan. Hasil Hasil Pengabdian Kepada Masyarakat menunjukkan bahwa terjadi peningkatan pengetahuan tentang pemanfaatan buku KIA, setelah dilakukan penyuluhan sehingga ibu hamil dapat memahami isi dari buku KIA
\end{abstract}

Kata kunci: $\quad$ stunting, pemanfaatan Buku KIA

PENDAHULUAN

Stunting adalah kondisi gagal pertumbuhan pada anak balita akibat kekurangan gizi kronis terutama pada 1.000 Hari Pertama Kehidupan (HPK). Keadaan gagal tumbuh pada anak balita disebabkan asupan gizi dalam waktu yang lama serta terjadi infeksi yang berulang, dan kedua faktor penyebabnya pola asuh yang tidak mendukung terutama dalam 1.000 HPK. (Kemenkes,2013)

1000 Hari pertama kehidupan anak dimulai sejak anak dalam kandungan ibu hingga dua tahun, ini merupakan masa-masa kritis dalam membantu pertumbuhan dan 
perkembangan anak secara optimal. Ibu hamil dengan konsumsi asupan gizi yang rendah dan mengalami penyakit infeksi akan mempengaruhi pertumbuhan anak.

Dampak stunting akan berdampak pada Sumber Daya Manusia (SDM) baik berdampak dalam jangka pendek menyebabkan gagal tumbuh dan jangka panjang menurunnya kapasitas intelektual. Kurangnya pengetahuan pada ibu mengenai kesehatan dan gizi sebelum dan pada masa kehamilan, serta setelah ibu melahirkan yang terdapat di salah satu di buku kesehatan ibu dan anak (KIA) yang diberikan sejak wanita dalam keadaan hamil sehingga tidak ibu tidak memanfaatkan buku KIA dengan Optimal.

Buku KIA merupakan alat komunikasi dan media informasi tentang kesehatan ibu dan anak mulai sejak masa hamil, persalinan, nifas, bayi baru lahir dan anak sampai usia 6 tahun. Buku KIA salah satu untuk mendeteksi masalah pertumbuhan dan perkembangan pada anak.

Faktor lingkungan salah satu berpengaruh terhadap stunting yaitu akses pelayanan kesehatan yang belum terpadu baik dalam penerapan sasaran, perencanaan kegiatan, peran dan tugas antarpihak. Akibatnya cakupan dan kualitas berbagai pelayanan kurang optimal. Kelas ibu hamil bermanfaat meningkatkan pengetahuan, mengubah pengetahuan dan sikap dengan dibantu oleh kader yang berperan aktif dalam memberikan informasi.

Untuk meningkatkan kualitas Kesehatan ibu dan Anak dalam memanfaatkan buku KIA dalam rangka pencegahan stunting. Maka dilakukan pengabdian masyarakat dengan memberikan pendampingan kepada peserta kelas ibu dan dibantu oleh kader, sehingga ibu hamil dan kader memiliki pemahaman yang sama tentang buku KIA

Pengabdian masyarakat ini bertujuan meningkatkan pengetahuan ibu hamil di Desa Pagar Batu Kecamatan Habinsaran Kabupaten Toba Tahun 2021. Dalam mencegah stunting dan Kader dapat membantu untuk mendampingi ibu dalam memahami penggunaan Buku KIA sehingga kualitas kesehatan ibu dan anak mengalami peningkatan terutama dalam menurunkan angka kejadian stunting di Desa Desa Pagar Batu Kecamatan Habinsaran Kabupaten Toba Tahun 2021

\section{METODE}

Kegiatan Pengabdian masyarakat ini dilakukan terlebih dahulu yaitu analisis situasi daerah yang mengalami peningkatan stunting, kerjasama dengan mitra, membuat materi penyuluhan yang sesuai degan tema dan dibutuhkan.

Melaksanakan pemberdayaan sebelumnya kepada ibu hamil dan ibu yang memiliki anak dalam pemanfaatan buku KIA, dilakukan evaluasi pada tahap penyuluhan dan diskusi dengan cara mengukur pengetahuan sebelum dan sesudah dengan membagikan kuesioner yang terkait dengan buku KIA.

Sasaran kegiatan ini adalah Ibu hamil dan Ibu balita di Desa Pagar Batu Kecamatan Habinsaran Kabupaten Toba Tahun 2021, jumlah sebanyak 30 peserta ibu hamil, Penyuluhan dilaksanakan di Puskesmas dengan membagikan kuesioner sebelum dilakukan penyuluhan( Pre-test ) dan sesudah dilakukan penyuluhan (Post-test)

\section{HASIL DAN PEMBAHASAN}

Hasil penilaian keberhasilan yang dilakukan penyuluhan kepada ibu hamil dengan cara pemberian kuesioner untuk mengukur pengetahuan Ibu hamil terhadap materi penyuluhan yang sudah disampaikan, berikut hasil pengukuran pengetahuan ibu hamil tersebut :

Tabel 1. Pengetahuan ibu hamil

\begin{tabular}{lllcll} 
No. & \multicolumn{2}{c}{ Nilai } & \multicolumn{2}{c}{ Pre test } & \multicolumn{2}{c}{ Post-Test } \\
& pengetahuan & $\mathrm{N}$ & $\%$ & $\mathrm{~N}$ & $\%$ \\
1 & Baik & 15 & 50 & 20 & 66,7 \\
2 & Cukup & 5 & 16,7 & 3 & 10 \\
3 & Kurang & 10 & 33,3 & 7 & 23,3
\end{tabular}


$\begin{array}{lllll}\text { Total } & 30 & 100 & 30 & 100\end{array}$

Dari tabel 1 diatas mengalami peningkatan pengetahuan pada ibu hamil yang diberikan penyuluhan dilihat dari hasil pada saat ibu dilakukan pre-test sebelum penyuluhan terdapat pengetahuan baik $15(50 \%)$ orang dan pengetahuan ibu yang cukup 5(16,7\%) orang, serta pengetahuan yang kurang sebanyak 10 $(3,33 \%)$. Hasil ini menunjukkan bahwa pengetahuan ibu hamil tentang pemanfaatan buku KIA masih kurang. Setelah diberikan penyuluhan post-tets mengalami peningkatan yaitu ibu yang memiliki pengetahuan Baik sebanyak $20(66,7 \%)$ orang dan pengetahuan cukup sebanyak 3(10\%) serta kurang 7 (23,3\%).

Pengetahuan sangat penting untuk membentuk tindakan seseorang, tindakan yang didasari pengetahuan akan lebih baik dari pada tindakan yang tidak didasari oleh pengetahuan. Jika seseorang memiliki tingkat pendidikan yang rendah, maka akan menghambat perkembangan respon orang tersebut terhadap penerimaan informasi dan nilai-nilai yang baru diperkenalkan.

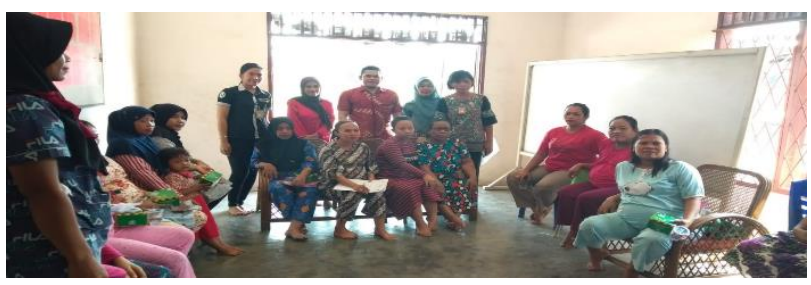

Gambar 1. Pemberian Materi

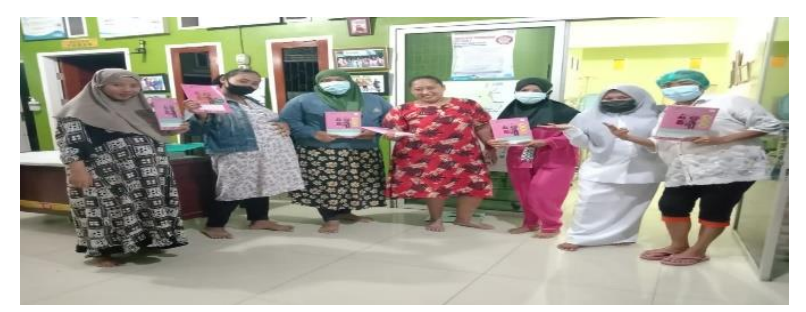

Gambar 2. Selesai pelaksanaan pemanfaatan buku KIA
Pemanfaatan buku KIA oleh ibu hamil dapat diikuti dengan adanya kelas ibu hamil sehingga meningkatkan pengetahuan, sikap dan perilaku ibu agar memahami tentang menjaga kehamilan, persiapan persalinan, perawatan nifas, dan perawatan bayi baru lahir dengan menggunakan buku KIA.

Buku KIA merupakan media informasi yang dapat memudahkan dalam menggunakannya tentang kualitas hidup kesehatan ibu dan anak secara detail. Buku KIA tersedia di Puskesamas, Poskesdes, bidan praktik, rumah bersalin dan rumah sakit.

\section{KESIMPULAN}

1. Terjadi peningkatan pengetahuan tentang pemanfaatan buku KIA, setelah dilakukan penyuluhan sehingga ibu hamil dapat memahami isi dari buku KIA di Desa Pagar Batu Kecamatan Habinsaran Kabupaten Toba Tahun 2021.

2. Membantu para Kader dalam melaksanakan pendampingan pemanfaatan Buku KIA pada Ibu.

\section{Ucapan Terima Kasih}

Penulis mengucapkan Terima kasih kepada pihak-pihak terkait dalam kegiatan ini. Terima kasih kepada kepala desa Desa Pagar Batu Kecamatan Habinsaran Kabupaten Toba Tahun 2021 yang telah memberikan izin kepada penulis untuk melaksanakan pengabdian kepada masyarakat. Terima kasih kepada kepada bidan desa dan kader yang sudah banyak membantu. Terima kasih kepada Bapak Drs. Imran Saputra Surbakti,.MM sebagai ketua pengurus yayasan Mitra Husada Medan. Terima kasih Kepada ibu Dr. Siti Nurmawan Sinaga, SKM, M.Kes selaku ketua STIKes Mitra Husada Medan yang memberikan motivasi kepada penulis. 


\section{DAFTAR PUSTAKA}

1. Ernawati, F. dkk. (2012). Studi Longitudinal Faktor Risiko Terjadinya Stunting pada Anak Baduta (Bawah Dua Tahun) (Penelitian Tahun ke-2). Pgi Terapan Kesehatan dan Epidemiologi Klinik Badan Litbangkes R

2. Mulyani, S. (2017). "Hubungan Tingkat Pengetahuan Dan Dukungan Keluarga Terhadap Kepatuhan Ibu Hamil Mengkonsumsi Tablet Zat Besi. Jambi Medical Journal" Jurnal Kedokteran dan Kesehatan", 5(2).

3. Kementerian Kesehatan RI, Buku Kesehatan Ibu dan Anak. Jakarta: Kementerian Kesehatan RI: 1997

4. Aridiyah FO, Rohmawati N, Ririanty M. (2015) Faktor-faktor yang mempengaruhi kejadian stunting pada anak balita di wilyah pedesaan dan perkotaan. E-jurnal Pustaka Kesehatan

5. Sutarto, Ratna, Trijayanti M. (2020). Pendampingan Pemanfaatan Buku Kesehatan ibu dan Anak sebagai upaya pencegahan Stunting di Desa Binaan Fakultas Universitas Lampung Tahun 2020. " jurnal pengabdian masyarakat Ruwai Jurai

6. Stranas Percepatan Pencegahan Stunting Periode 2018-2024 